J. Perinat. Med. 6 (1978) 95

\title{
Clinical investigations of the influence of various naloxone* doses on the newborn
}

\author{
W. Dick, E. Knoche, E. Traub
}

Department of Anesthesiology (Co-Directors: Prof. Dr. F. W. Ahnefeld and Prof. Dr. W. Dick), Center for Interdisciplinary Medical Units, University of Ulm

Maternally administered opiate analgesics may cause a respiratory depression of the newborn. Such respiratory depression is often not diagnosed with purely clinical methods such as the APGAR score. However, laboratory and clinical - experimental methods may demonstrate a neonatal depression more clearly $[2,3,13]$.

It has been well documented that the maximal effect of meperidine occurs within 30-60 minutes after administration to the mother but that a neonatal depression may be recognized as late as 2-4 hours after administration of meperidine $[2,9,12]$.

Opiate antagonists have frequently been recommended for the prophylaxis of postpartum adaption disturbances caused by opiates. Basically two kinds of antagonists exist [9]: Agonistantagonists such as nalorphine and levallorphan on the one hand and pure antagonists such as naloxone on the other hand. Agonist-antagonists may cause a respiratory depression if they are over-dosed or if there is no opiate present on the receptor site. This effect is not present with naloxone. If naloxone is given to the mother $5-15$ minutes before birth or is injected immediately postpartum into the umbilical vein, the agent will prevent a postpartum neonatal respiratory depression $[4,5$, $6,7,8,9,10,14]$. Various doses have been re-

\footnotetext{
* Narcan ${ }^{\circledast}$, Endo-L,ab, Inc.
}

J. Perinat. Med. 6 (1978) commended for the umbilical vein injection $[4,6$, $7,8,9,11]$.

The purpose of this study was to investigate the influence of various naloxone doses on the postpartum course of neonatal blood gases and acidbase status following injection into the umbilical vein.

\section{Experimental design and experimental groups}

The study was carried out in two parts. Part I refers to 40 newborns randomly distributed into four groups. The newborns of Group $I / 1$ were the controls; they had the usual postpartum care and did not receive naloxone. Neonates in Group I/2 received $0.02 \mathrm{mg} / \mathrm{kg}$ naloxone into the umbilical vein, infants in Group I/3 received $0.03 \mathrm{mg} / \mathrm{kg}$ and those in Group I/4 $0.04 \mathrm{mg} / \mathrm{kg}$ of naloxone.

In Part II there were 30 newborns randomly distributed into three groups. The infants in Group II/1 received immediately postpartum an umbilical venous injection of placebo, those in Group II/2 $0.04 \mathrm{mg} / \mathrm{kg}$ naloxone, and those in Group $\mathrm{II} / 3$ $0.04 \mathrm{mg}$ naloxone.

Part II of this study was designed as a double blind study where examiner and follow-up examiner were not informed about the agent or the dose. Placebo and the varying amounts of naloxone doses were distributed in equal amounts of volume and thus indistinguishable. The mothers of all newborns received at a cervical dilation of $3-4 \mathrm{~cm}$ 
$0.1 \mathrm{mg} / \mathrm{kg}$ of dehydrobenzperidol and $0.4 \mathrm{mg} / \mathrm{kg}$ of meperidine intravenously. The usual clinical variables and blood gases were recorded 30 minutes after the administration. When labor pain increased again, another dose of $0.4 \mathrm{mg} / \mathrm{kg}$ of meperidine was injected intravenously at the mother's request. One, five and ten minutes after birth the Apgar status of the newborn, blood gas and acid-base examinations were performed. Blood gas and acid-base status was repeated at 30,60 and 120 minutes after birth. The blood samples were obtained from the hyperemized heel. $\mathrm{pH}, \mathrm{PCO}_{2}$, base-excess standard bicarbonate, and $\mathrm{PO}_{2}$ were obtained with the ASTRUP apparatus and the SIGGAARD-ANDERSON nomogram.

\section{Results}

\subsection{Part I}

The maternal age was between 25.5 and 28.2 years, their mean weight was 67.7 to $71.3 \mathrm{~kg}$. The duration of labor was between 107.8 and 144.8 minutes, and the time between the last meperidine dose and birth was between 66 and 96.1 minutes. The intravenous dose of meperidine was 0.42 to $0.53 \mathrm{mg} /$ minute, which corresponds to 0.39 to $0.44 \mathrm{mg} / \mathrm{kg} /$ hour.

The birth weight of the newborns in Part I of this study was between 3.255 and $3.550 \mathrm{~kg}$.

At the time of delivery the mean maternal $\mathrm{pH}$ values were between 7.38 and $7.40, \mathrm{PCO}_{2}$ between 29.02 and $34.68, \mathrm{PO}_{2}$ between 85.5 and $90.4 \mathrm{~mm}$ $\mathrm{Hg}$. The mean base-excess values were -5.76 to $-6.17 \mathrm{mval} / \mathrm{l}$.

There were no statistically relevant differences between the neonatal $\mathrm{pH}$ values in all four groups (Fig. 1). The same was true for the neonatal $\mathrm{PCO}_{2}$ values (Fig. 2).

However, a statistically significant difference was seen for the difference of the $\mathrm{PCO}_{2}$ values from the base line value at one minute $\left(\triangle \mathrm{PCO}_{2}\right) 30$ and 60 minutes after birth in groups 2 and $4(0.02$ and $0.04 \mathrm{mg} / \mathrm{kg}$ ). In the two naloxone groups the $\mathrm{PCO}_{2}$ values decreased more markedly when compared to the control group at $\mathbf{3 0}$ and $\mathbf{6 0}$ minutes after birth (Fig. 3).

Neither the absolute nor the difference values to the base line for $\mathrm{PO}_{2}\left(\Delta \mathrm{PO}_{2}\right)$ were significantly

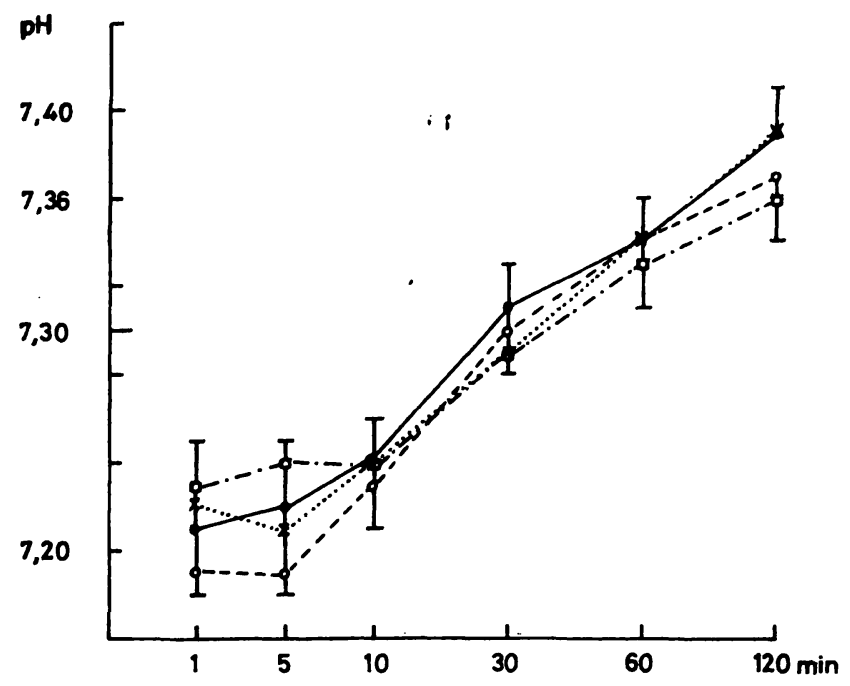

Fig. 1. $\mathrm{pH}$ values after birth in relation to various naloxone doses.

\begin{tabular}{l}
$\bullet-\bullet$ controls \\
\hdashline$--00.02 \mathrm{mg} / \mathrm{kg}$ naloxone \\
$\times \ldots \times 0.03 \mathrm{mg} / \mathrm{kg}$ naloxone \\
.$--.0 .04 \mathrm{mg} / \mathrm{kg}$ naloxone
\end{tabular}

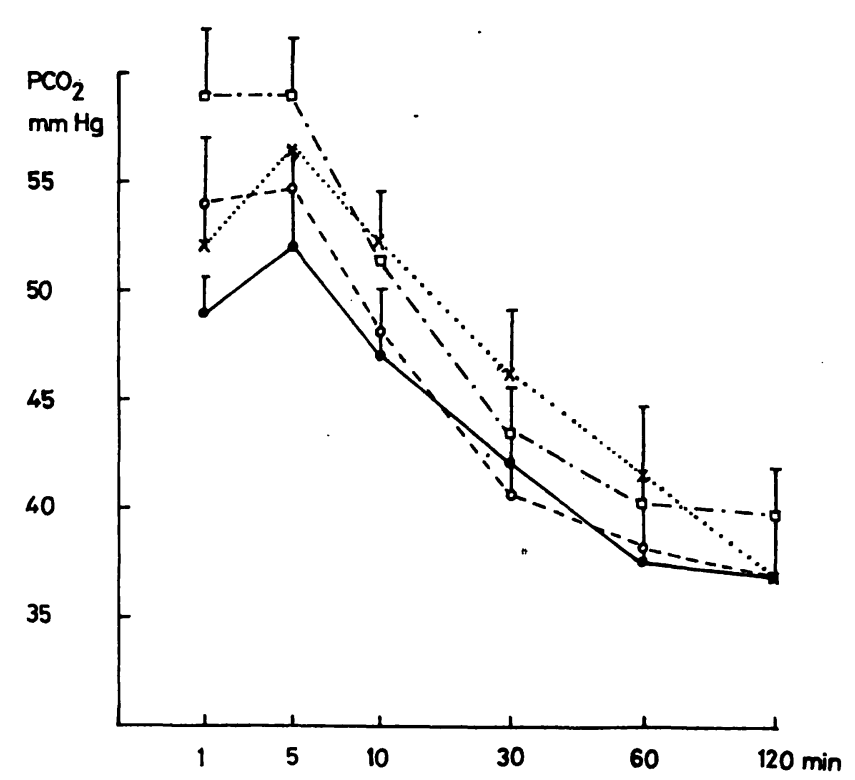

Fig. 2. $\mathrm{PCO}_{2}$ values in neonates following various naloxone doses. See legend for Figure 1.

different between the control group and the naloxone groups (Fig. 4).

Thus, it was documented that under the conditions of the experiment (dose of meperidine, interval between meperidine and birth, etc) there were no significant differences between the controls and 


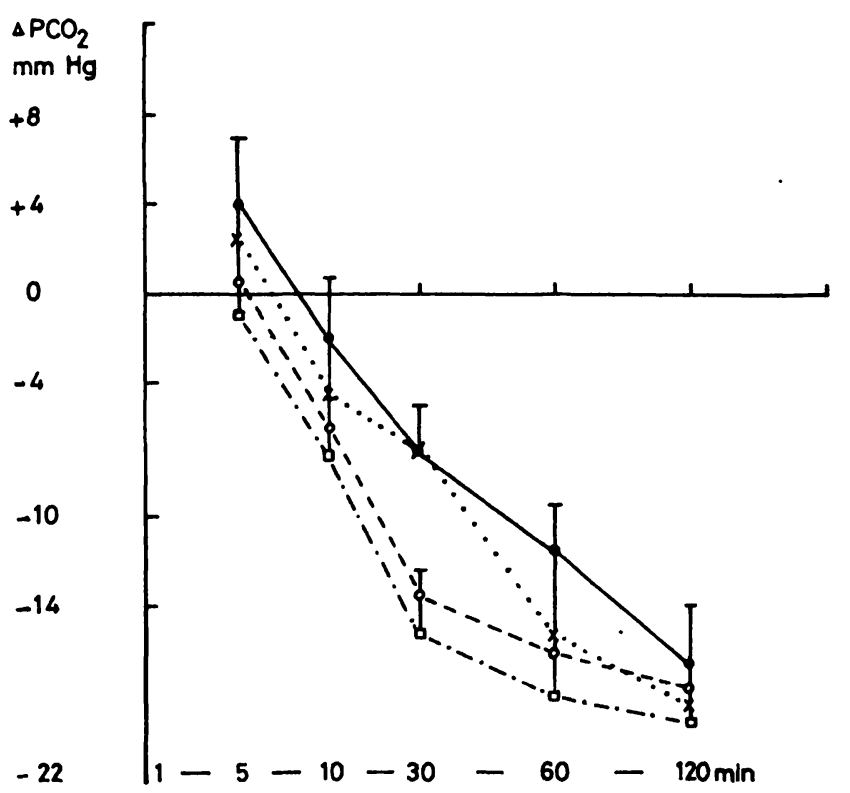

Fig. 3. $\triangle \mathrm{PCO}_{2}\left(=\right.$ difference between $\mathrm{PCO}_{2}$ at a particular point in time and the base line value 1 minute after birth). An increase of $\triangle \mathrm{PCO}_{2}$ indicates an increase of the $\mathrm{PCO}_{2}$ value from the base line. See legends for Figure 1.

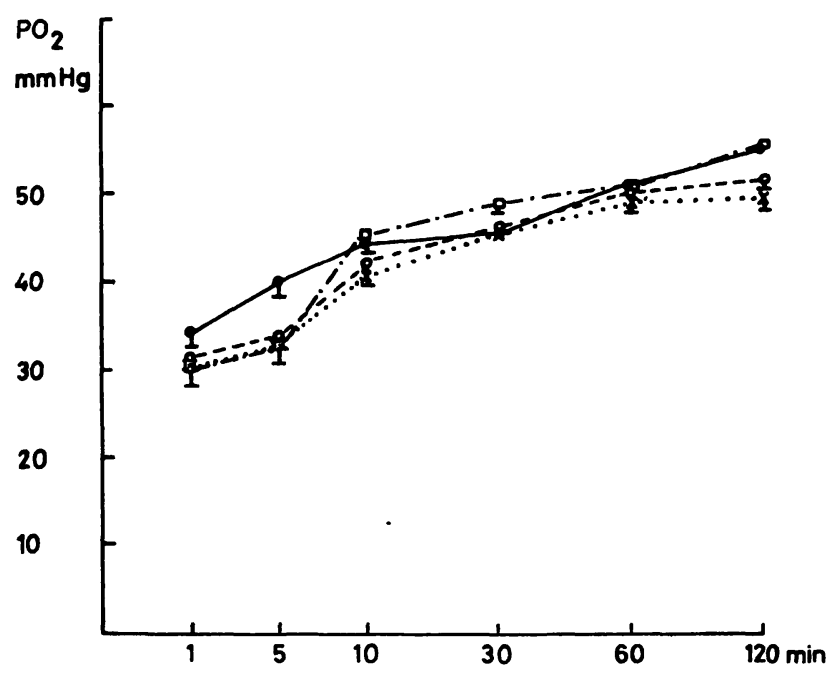

Fig. 4. $\mathrm{PO}_{2}$ values in neonates in relation to various naloxone doses.

experimental groups: however, the decrease in the $\mathrm{PCO}_{2}$ values in naloxone groups $\mathrm{I} / 2$ and $\mathrm{I} / 4$ were more marked than that in the control group. In order to verify this effect in a double blind experiment a new control group and a naloxone group with a dose of $0.04 \mathrm{mg} / \mathrm{kg}$ were compared with each other. Added to this experimental group were ten newborns who received only $0.04 \mathrm{mg}$ of naloxone.

\subsection{Part II}

The age of the mothers in Part II was between 25.7 and 26.6 years, they weighed between 70.1 and $75.6 \mathrm{~kg}$. Dehydrobenzperidol was given in total doses between 7.0 and $7.6 \mathrm{mg}$; the todal dose of meperidine was between 32.4 and $61.5 \mathrm{mg}$. The duration of labor was between 81.7 and 186.7 minutes, the administration of meperidine between 0.39 and $0.7 \mathrm{mg} / \mathrm{minute}$ or 0.33 to $0.56 \mathrm{mg} / \mathrm{kg} /$ hour respectively. The time between the last dose of meperidine and birth was 54.5 to 69.7 minutes. The newborns in Part II of the study weighed between 3247 and 3338 grams. Maternal pH, $\mathrm{PCO}_{2}, \mathrm{PO}_{2}$ and base-excess values in all three study groups of Part II were nearly identical and there were no statistically significant differences.

The $\mathrm{pH}$ values of the newborn were not statistically different in all three groups (Fig. 5). The same was true for the absolute $\mathrm{PCO}_{2}$ values (Fig. 6). While the $\mathrm{PCO}_{2}$ differences in comparison to the base line value were higher in both naloxone groups than the control group, this was statistically significant only for ten minutes after birth $(P<0.05)$; the differences were not significant for the other intervals (Fig. 7). $\mathbf{P O}_{2}$ and base-excess values did not differ in either the absolute values or the differences to the base line (Fig. 8).

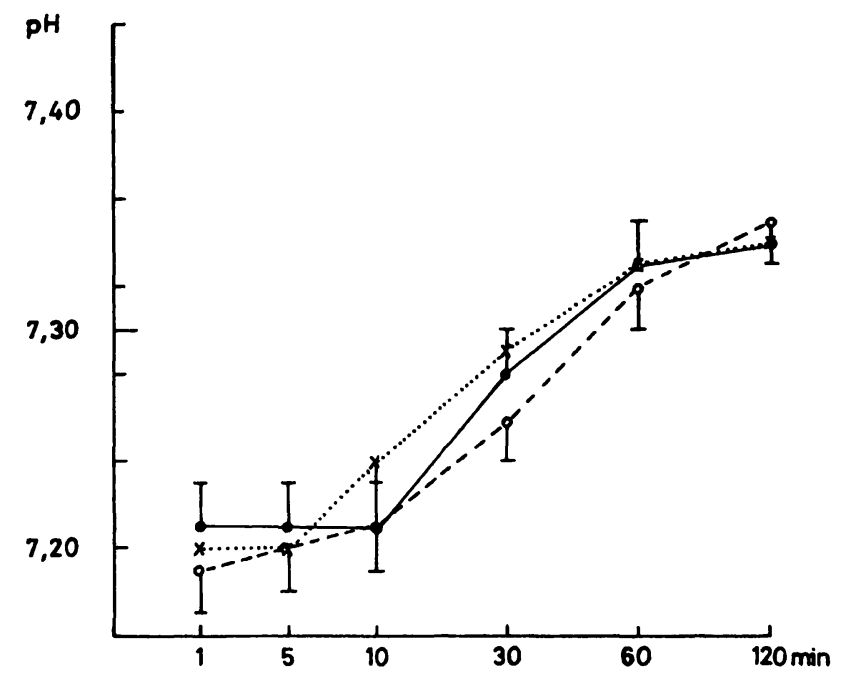

Fig. 5. $\mathrm{PO}_{2}$ values in groups $\mathrm{II} / 1-3$

$-\longrightarrow$ controls

- - $00.04 \mathrm{mg} / \mathrm{kg}$ naloxone

x. ... x $0.04 \mathrm{mg}$ naloxone

Indicated are means and standard deviation of the mean. 


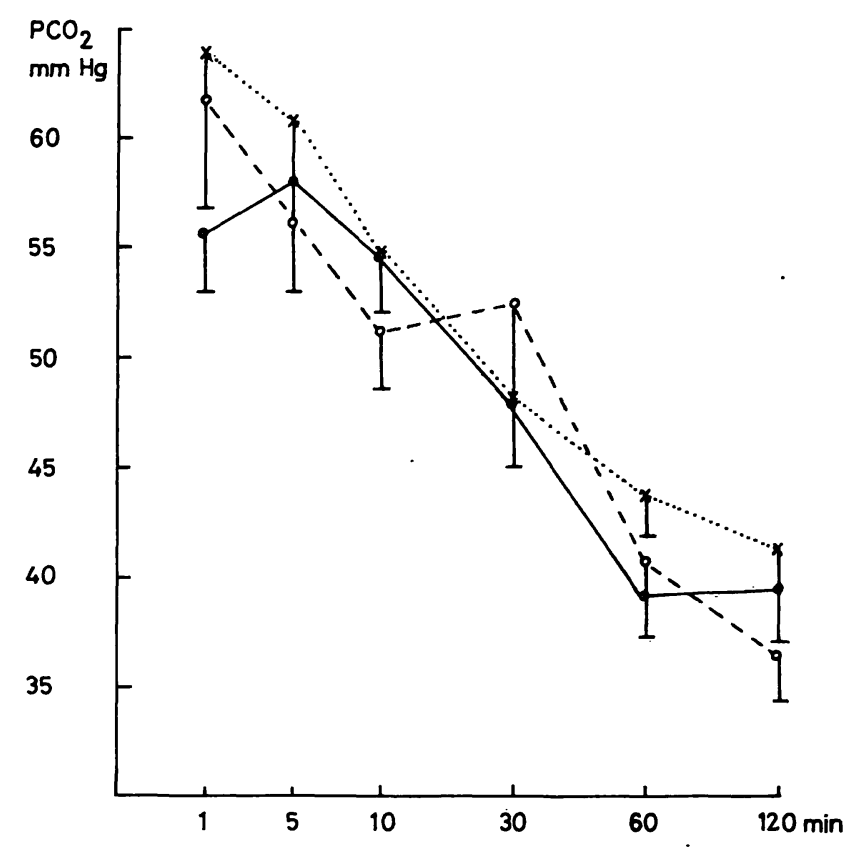

Fig. 6. $\mathrm{PCO}_{2}$ values in groups $\mathrm{II} / 1-3$. See legend for Figure 5 .

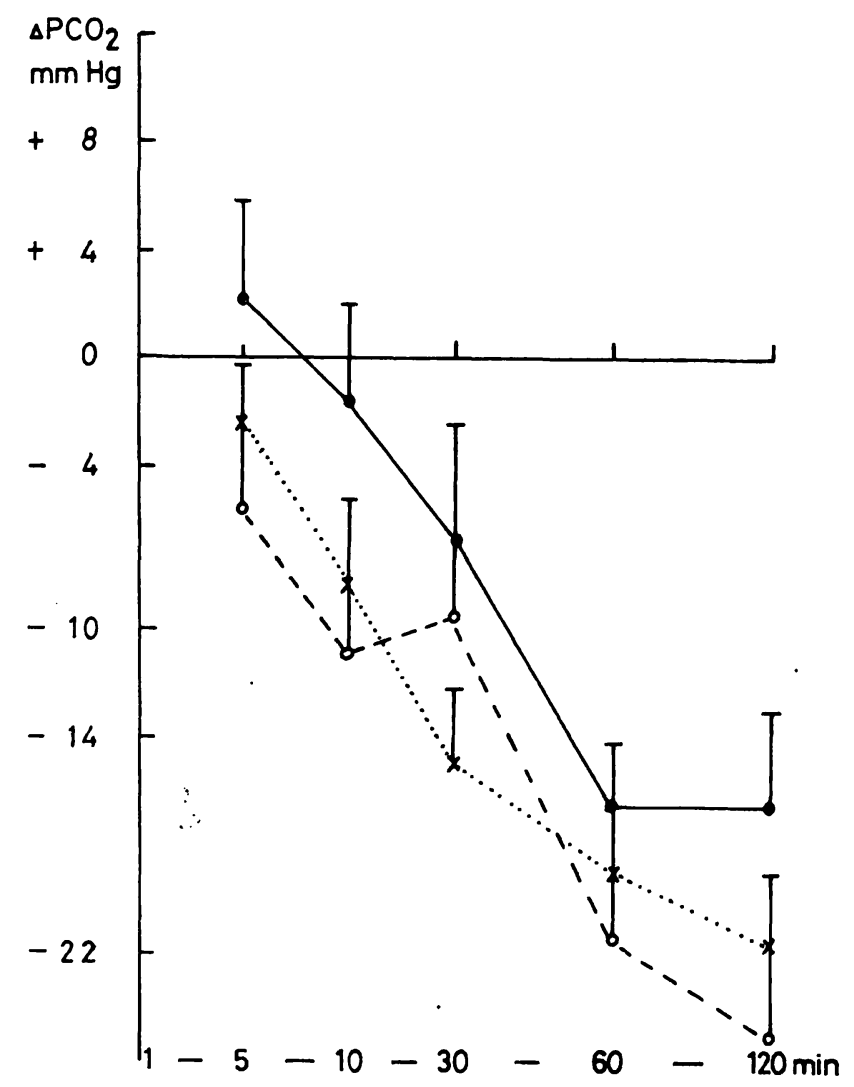

Fig. 7. Course of $\Delta \mathrm{PCO}_{2}$ in groups $\mathrm{II} / 1-3$. See legend for Figure 5.

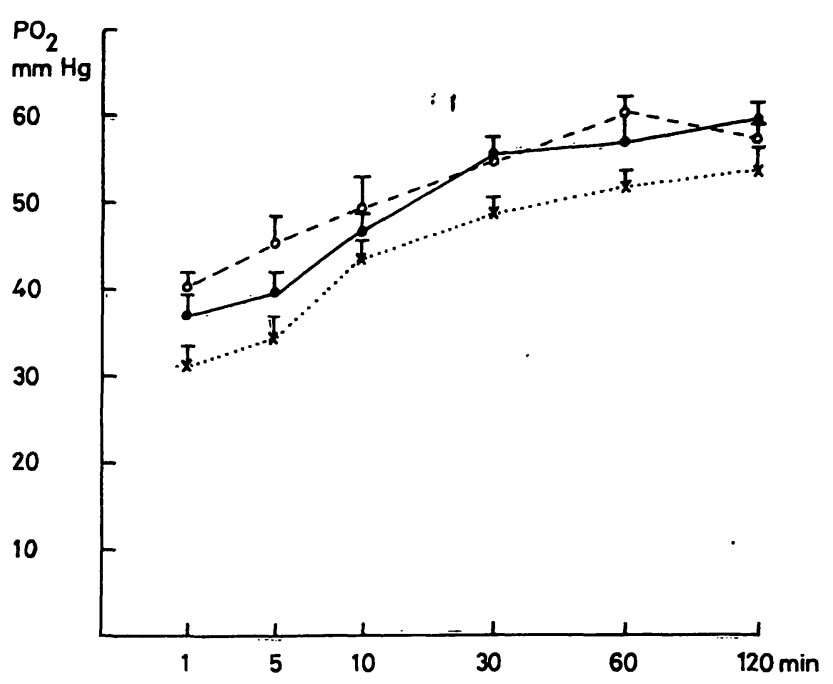

Fig. 8. Course of $\mathrm{PO}_{2}$ values in groups II/1-3. See legend for Figure 5.

\section{Discussion}

The efficacy of in travenously administered naloxone for the prophylaxis and therapy of opiate-related neonatal respiratory depression has been demonstrated by various authors with different methods. GERHARDT et al [10] demonstrated an increase in ventilation following $0.1 \mathrm{mg} / \mathrm{kg}$ of narcan. The investigation of EvaNs [7, 8] with $40 \mu \mathrm{g}$ did not show any significant increase in respiratory frequency and alveolar ventilation but the $\mathrm{PCO}_{2}$ values were markedly lower in the naloxone group than in the control group. Similar results were found by WIENDER and ROSEN" [14].

In Part I of this study we demonstrated a markedly lower $\mathrm{PCO}_{2} 30$ and 60 minutes after birth in the two groups $\left(\Delta \mathrm{PCO}_{2}\right)$. The double blind study did not verify this effect at the same times, but there was a statistically significant difference five minutes after the administration of naloxone.

There is no difference in the postpartum $\mathrm{PO}_{2}$ values between the various groups.

Thus, our results differ from the results of some authors but concur with the findings of CHANG et al, Clark et al and Martin et al $[4,5,11]$. The reason for the different results has to be the dose of the agent and the different dose of meperidine. MARTIN [11] used mean meperidine doses of $97.4 \mathrm{mg}$, but did not record the total dose nor the 
interval between the last dose and delivery. The study by CLARK [5] mentioned total doses of Meperidin between 150 and $500 \mathrm{mg}$ distributed over several sub-doses. ROSEN and Evans [7, 8, 14] record the total dose of meperidine administered and its level in the umbilical vein at the time of delivery but these authors did not measure capillary blood gas values and acidbase status while recording alveolar $\mathrm{PCO}_{2}$ and $\mathrm{CO}_{2}$ production.

The meperidine doses in our study are relatively low. According to the „Reisensburg recommendations" [1] intravenous application of low doses of meperidine establishes a base line sedation and analgesia; the patients at their request received additional low doses of analgesics intravenously.

Thus, the results of these various investigations differ in methodology and the dose of meperidine. Therefore, the basic situation of the experiment, namely, the degree of the postpartum respiratory depression of the newborn, differ in those studies. The primary reason for the differences should be the variously high doses of meperidine and the varyinglong intervals between last dose of meperidine and delivery. Possibly the routes of administrationin tramuscularly vs intravenously-are also important.

Thus, it may be assumed in those studies in which a marked and statistically significant respiratory effect was demonstrated, that there was a notable respiratory depression of the newborn. In the group responding poorly only a minor degree of

\section{Summary}

The influence of postpartum injections of various doses of naloxone on the blood gases and acid base status of 70 newborns was investigated. In Part I of the experiment groups of 10 newborns each received $0.02,0.03$, or 0.04 $\mathrm{mg} / \mathrm{kg}$ naloxone through the umbilical vein immediately after birth; there was a control group of 10 neonates. Part II of the experiment comprised three groups of ten newborns each received immediately after birth into their umbilical veins an injection of placebo (group 1), $0.04 \mathrm{mg} /$ $\mathrm{kg}$ naloxone (group 2), or $\mathbf{0 . 0 4} \mathrm{mg}$ naloxone (group 3). The second experiment was conducted as a double blind study.

All mothers received during labor $0.1 \mathrm{mg} / \mathrm{kg}$ dehydrobenzperidol and $0.4 \mathrm{mg} / \mathrm{kg}$ meperidine intravenously when the cervical dilatation was $3-4 \mathrm{~cm}$. Additionally, $0.4 \mathrm{mg} / \mathrm{kg}$ of meperidine was given again if labor pain increased.

The mean duration of labor was between 81.7 and 186.7 minutes; the time between the last dose of meperidine respiratory depression of the newborn may have been present. Thus, those newborns in which there was no effect should be classified as being depressed not due to opiates.

They demonstrate that naloxone in itself does not cause respiratory depression even if the agent is overdosed or there is no meperidine on the receptor site.

In summary, our study and those. previously published allow the following conclusions:

1. The use of naloxone in the newborn in the postpartum period has no negative effects (in contrast to nalorphin and levallorphan)

2. In the presence of respiratory depression there is a significantly faster $\mathrm{CO}_{2}$ elimination (higher $\triangle \mathrm{PCO}_{2}$ values) than without the use of naloxone.

3. An optimal dose has not been established in this study. While $0.04 \mathrm{mg} / \mathrm{kg}$ had a stronger effect in the first part of the experiment than $0.02 \mathrm{mg}$ and $0.03 \mathrm{mg} / \mathrm{kg}$, but it was also seen that 0.02 $\mathrm{mg} / \mathrm{kg}$ was more effective than $0.03 \mathrm{mg} / \mathrm{kg}$.

The second part of the study demonstrated that the administration of $0.04 \mathrm{mg} / \mathrm{kg}$ is as much or as little effective as is the injection of $0.04 \mathrm{mg}$ as a total dose.

For clinical purposes the conclusion may be drawn that if an opiate-related respiratory depression of the newborn is suspected it may be treated without risk and with a dependable effect by the administration of naloxone.

and birth was between 54.4 and 96 minutes. The mean dose of meperidine was between 0.39 and $0.7 \mathrm{mg} /$ minute or 0.33 to $0.56 \mathrm{mg} / \mathrm{kg}$ hour respectively. The course of the neonatal $\mathrm{pH}$ values $\mathrm{PCO}_{2}$ and $\mathrm{PO}_{2}$ up to two hours after birth in the first part of the experiment was not different. However, the $\Delta \mathrm{PCO}_{2}$, i.e. the difference of the $\mathrm{PCO}_{2}$ values at the various measuring intervals from the base line value 1 minute after birth for groups 2 and 4 was statistically significantly lower at 30 and 60 minutes than the control group or group 3.

The experimental design of a double blind study in Part II of these studies again showed no differences in regard to $\mathrm{pH}, \mathrm{PCO}_{2}, \mathrm{PO}_{2}$, or base-excess values. While the $\mathrm{PCO}_{2}$ differences from the base line value were larger than the control group, this was significant only for ten minutes after birth.

Thus, the experiments allow the conclusion that the use of naloxone in the neonate during the postpartum period has no negative effects. In respiratory depression the $\mathrm{CO}_{2}$ 
may be eliminated markedly faster than without the use of naloxone. Adequate doses are $0.04 \mathrm{mg}$ as total dose or 0.01 or $0.02 \mathrm{mg} / \mathrm{kg}$. An opiate-related respiratory depression of the newborn can be treated without risk and reliably by the use naloxone as an antagonist.

Keywords: acid-base status, analgesia, antagonist, birth, blood gases, dehydrobenzperidol, naloxone, neonate, meperidine, respiratory depression.

\section{Zusammenfassung:}

Klinische Untersuchungen zum Einfluß unterschiedlicher Naloxon-Dosen auf das Neugeborene post partum.

An insgesamt 70 Neugeborenen wurde der Einfluß der postpartalen Injektion unterschiedlicher Dosen von Naloxon auf die Blutgase und die Parameter des SäurenBasen-Haushaltes untersucht. In Teil I erhielten je 10 Neugeborene 0,02 bzw. 0,03 bzw. $0,04 \mathrm{mg} / \mathrm{kg}$ Naloxon unmittelbar postpartal in die Nabelvene injiziert, $10 \mathrm{Neu}$ geborene dienten als Kontrollgruppe. Teil II der Untersuchungen bezog sich auf 30 Neugeborene, die wiederum randomisiert auf 3 Gruppen verteilt waren. Die Neugeborenen der Gruppe 1 erhielten unmittelbar postpartal Placebo in die Nabelvene injiziert, die Neugeborenen der Gruppe $20,04 \mathrm{mg} / \mathrm{kg}$ Naloxon und die Neugeborenen der Gruppe 3 0,04 mg Naloxon. Teil II der Untersuchungen war als Doppelblindversuch angelegt.

Alle Mütter hatten unter der Geburt initial bei einer Muttermundsweite von $3-4 \mathrm{~cm} 0,1 \mathrm{mg} / \mathrm{kg}$ Dehydrobenzperidol und $0,4 \mathrm{mg} / \mathrm{kg}$ Dolantin intravenös injiziert erhalten. Sobald die Wehenschmerzen wieder zunahmen, wurden jeweils weitere $0,4 \mathrm{mg} / \mathrm{kg}$ Dolantin intravenös nachinjiziert.

Die Geburtsdauer betrug durchschnittlich zwischen 81,7 und 186,7 min, die Zeit zwischen der letzten DolantinApplikation und der Geburt zwischen 54,4 und $96 \mathrm{~min}$. Der intravenöse Dolantin-Verbrauch lag im Mittel zwischen 0,39 und $0,7 \mathrm{mg} / \mathrm{min}$ bzw. $0,33-0,56 \mathrm{mg} / \mathrm{kg} / \mathrm{h}$.

Der bis $\mathrm{zu} 2 \mathrm{~h}$ nach der Geburt verfolgte neonatale $\mathrm{pH}$ Wertverlauf ließ innerhalb des I. Teils der Untersuchungen keinen statistisch relevanten Unterschied erkennen. Das gleiche traf auf die $\mathrm{PCO}_{2}$-Werte und die $\mathrm{PO}_{2}$-Werte $\mathrm{zu}$.
Wurde jedoch $\triangle \mathrm{PCO}_{2}-$ d. h. die Differenz der $\mathrm{PCO}_{2-}$ Werte zu den jeweiligen Meßzeitpunkten gegenüber dem Ausgangswert 1 min nach der Geburt - gebildet, so ergab sich in den Gruppen 2 und $4(0,02-0,04 \mathrm{mg} / \mathrm{kg})$ ein statistisch signifikanter Unterschied gegenüber der Kontrollgruppe und der Gruppe 3; die $\mathbf{P C O}_{2}$-Werte dieser beiden Gruppen waren 30 und 60 min nach der Geburt ausgeprägter abgefallen als die $\mathrm{PCO}_{2}$-Werte der übrigen Gruppen.

Auch unter den Bedingungen des Doppelblindversuches Teil II der Untersuchungen - zeigten sich im pH-Wertverlauf, im Verlauf der $\mathrm{PCO}_{2-}, \mathrm{PO}_{2-}$ und Base-ExcessWerte keine statistisch relevanten Unterschiede $\mathrm{zwischen}$ den Gruppen. Wenn auch die $\mathrm{PCO}_{2}$-Differenzen wiederum gegenüber dem Ausgangswert in beiden Naxolon-Gruppen erheblich größer waren als in der Kontrollgruppe, so ließ sich doch ein statistisch relevanter Unterschied lediglich 10 min nach der Geburt auf dem 5\%-Niveau nachweisen $\left(\Delta \mathrm{PCO}_{2}\right)$.

Damit lassen die durchgeführten Untersuchungen die Schlußfolgerung zu, daß die Applikation von Naloxon an das Neugeborene in der postpartalen Phase ohne negative Auswirkungen ist, daß in Anwesenheit einer Atemdepression eine deutlich schnellere $\mathrm{CO}_{2}$-Elimination zu erwarten ist als ohne die Applikation von Naloxon und $\mathrm{daß}$ eine adäquate Dosierung bereits mit $0,04 \mathrm{mg}$ als Gesamtdosis bzw. ca. 0,01-0,02 mg/kg erreicht wird. Wenn eine opiatbedingte respiratorische Depression des Neugeborenen vorliegt oder vermutet werden kann, läßt sich diese ohne Risiko und mit zuverlässigem Éffekt durch Naloxon antagonisieren.

Schlüsselwörter: Antagonisten, Atemdepression, Blutgase, Dehydrobenzperidol, Geburt, Naloxon, Neugeborenes, Pethidin, Säure-Basen-Status, Schmerzbekämpfung.

\section{Résumé:}

Etude clinique sur l'influence de doses diverses de naloxone post partum chez les nouveaux-nés

Une étude a été faite chez 70 nouveaux-nés choisis au hasard sur l'influence de l'injection postpartale de doses diverses de naloxone sur les gaz sanguins et des paramètres de teneur acidobasique. L'analyse a porté en lère partie sur 4 groupes de 10 nouveaux-nés, les trois premiers ayant reçu respectivement une injection postpartale immédiate dans la veine ombilicale de $0,02,0,03$ et $0,04 \mathrm{mg} / \mathrm{kg}$ de naloxone et le quatrième servant de groupe de contrôle. La Ilème partie des analyses a porté, à titre de test témoin double sur 30 nouveaux-nés répartis en trois groupes. Ceux du groupe I ont reçu de la même façon une injection de placebo, ceux du groupe II $0,04 \mathrm{mg} / \mathrm{kg}$ de naloxone et ceux du groupe III $0,04 \mathrm{mg}$ de naloxone.

Une injection intraveineuse de $0,1 \mathrm{mg} / \mathrm{kg}$ de déhydrobenzpéridol et de $0,4 \mathrm{mg} / \mathrm{kg}$ de dolantine avait été initialement administrée à toutes les mères lorsque l'ouverture de l'utérus avait atteint $3-4 \mathrm{~cm}$; cette injection avait été suivie d'une ou de plusieurs autres de $0,4 \mathrm{mg} / \mathrm{kg}$ de dolantine à la reprise des douleurs.

Les accouchements ont duré en moyenne de 81,7 à 186,7 min., le temps écoulé entre la dernière administration de dolantine et l'accouchement se situant entre 54,4 et 96 min. La quantité totale moyenne de dolantine injectée a été de 0,39 à $0,7 \mathrm{mg} / \mathrm{min}$. ou de 0,33 à $0,56 \mathrm{mg} / \mathrm{kg} / \mathrm{h}$. 
En ce qui concerne la première partie des analyses, l'observation des valeurs de $\mathrm{pH}$ néonatal ainsi que du $\mathrm{PCO}_{2}$ et du $\mathrm{PO}_{2}$ durant les deux heures successives à l'accouchement n'a donné aucun résultat significatif. Par contre, $\triangle \mathrm{PCO}_{2}$ - c.àd. l'analyse des différences entre les valeurs de $\mathrm{PCO}_{2}$ $5,10,30,60$ et $120 \mathrm{~min}$. après l'accouchement et les valeurs initiales du $\mathrm{PCO}_{2} 1 \mathrm{~min}$. après l'accouchement a montré un écart statistiquement important entre les groupes 2 et 4 d'une part et le groupe de contrôle d'autre part: l'administration de 0,02 et de $0,04 \mathrm{mg} / \mathrm{kg}$ de naloxone a provoqué, en effet, 30 et $60 \mathrm{~min}$. après l'accouchement une baisse plus rapide et plus forte du $\mathrm{PCO}_{2}$.

De même, dans le test témoin double - llême partie des analyses - on n'a observé aucune différence importante entre les valeurs de $\mathrm{pH}$, de $\mathrm{PCO}_{2}$, de $\mathrm{PO}_{2}$ et de $\mathrm{BE}$ des trois groupes.

Et bien que les écarts du $\mathrm{PCO}_{2}$ relevé $5,10,30,60$ et 120 min. après l'accouchement et comparé aux valeurs d'une minute aient été beaucoup plus grands que pour le groupe de contrôle, on n'a pu retenir un résultat significatif du point-de-vue statistique que pour les valeurs enregistrées $10 \mathrm{~min}$. après l'accouchement.

En conclusion, nous pouvons résumer les données obtenues comme suit:

1. l'administration de naloxone aux nouveaux-nés après l'accouchement n'a produit aucun trouble chez ces derniers,

2. dans les cas de dépression respiratoire foetale et néonatale causée par les analgésiques narcotiques, l'administration de naloxone est susceptible d'accélérer et d'accroître l'élimination de $\mathrm{CO}_{2}$ et de stimuler la respiration, la dose la plus bénéfique se situant probablement entre $0,01-0,02 \mathrm{mg} / \mathrm{kg}$ ou $0,04 \mathrm{au}$ total.

Ceci signifie qu'en cas de dépression respiratoire néonatale dûe à des analgésiques narcotiques, on peut administrer du naloxone sans danger et avec succès.

Mots-clés: Analgésie, antagonistes, déhydrobenzpéridol, dépression respiratoire, gaz sanguins, naissance, naloxone, nouveau-né, péthidine, statut acido-basique.

\section{Bibliography}

[1] AHNEFELD, F. W., C. BURRI, W. DICK, M. HALMAGYI: Anästhesie in der Geburtshilfe und Gynäkologie. Schriftenreihe Klinische Anästhesiologie, Bd. 4 Lehmanns-Verlag 1974, München

[2] ALDERMAN, M. M.: Reducing the risks of OB anesthesia. patient care 1 (1974) 155

[3] BRACKBILL, Y., J. KANE, R. L. MANIELlo, D. ABRAMSON: Obstetric meperidine usage and assessment of neonatal status. Anesthesiology 40 (1974) 116

[4] ChANG, A., M. GILBERT, C. WOOD, M. HUMPHREY: The effects of nalorphine and naloxone on maternal and fetal blood gas and pH. Med. J. Aust. 1 (1976) 263

[5] CLARK, R. B.: Transplacental reversal of meperidine depression in the fetus by naloxone. J. Arkansas Med. Soc. 68 (1971) 4

[6] CLARK, R. B., A. G. BEARD, E. GREIFENSTEIN, D. L. BARCLAY: Naloxone in the parturient and her infant. South. Med. J. 69 (1976) 570

[7] EVANS, J. M.: The effect of naloxone on the early respiratory depressant effect of maternal pethidine analgesia. IV. European Congress of Anaesthesiology September 1974, Madrid

[8] EVANS, J. M., M. I. J. HOGG, M. ROSEN: The effect of naloxone on the depression of the early respiratory activity of neonates produced by maternal pethidine analgesia. Recent Progress in Anaesthesio- logy and Resuscitation. Eds. Arias, Laurado et al., Pub. by Excerpta Medica, Amsterdam 1975, p. 72

[9] FOLDES, F. F.: The human pharmacology and clinical use of narcotic antagonists. Med. Clin. N. Amer. 48 (1964) 421

[10] GERHARDT, T., E. BANCALARI, H. COHEN, L. F. ROCHA, K. HOLSINGER: Reversal of narcotic respiratory depression in the newborn with naloxone. American Society of Anesthesiologists Annual Meeting Palmer House/Hyatt Regency Chicago Chicago/Ill., Oktober 1975

[11] MARTIN, K., P. G. KNAPSTEIN, F. MELCHERT, H. SCHÄFER, K. W. TIETZE: Klinische Erfahrungen mit dem Opiat-Antagonisten Naloxone beim Neugeborenen. Vortrag 143. Tagung der Mittelrheinischen Gesellschaft für Geburtshilfe und Gynäkologie. Saarbrücken, 10.-11. 6. 1972

[12] RICCIARELLI, A.M., B. B. GUTSCHE, T.C. SMITH, Opioids and obstetrics. Clin. Obstet. and Gynec. 17 (1974) 259

[13] SCANLON, J. W., W. U. BROWN, J. B. WEISS, M. H. ALPER: Neurobehavioral responses of newborn infants after maternal epidural anesthesia. Anesthesiology 40 (1974) 121

[14] WIENER, P. C., M. ROSEN: The effects of naloxone on pethidine induced depression of the newborn. Department of Anaesthetics, University Hospital of Wales, Heath Park, Cardiff, CF 44 XW

Received November 18, 1976. Accepted January 10, 1977

Prof. Dr. W. Dick

Univ. Ulm

Dept. Anesthesiol.

P.O. Box 554

D-7900 Ulm 